\title{
Transformative remedies towards managing diversity in South African theological education
}

\begin{tabular}{|c|c|}
\hline \multicolumn{2}{|c|}{$\begin{array}{l}\text { Author: } \\
\text { Marilyn Naidoo }{ }^{1}\end{array}$} \\
\hline \multicolumn{2}{|c|}{$\begin{array}{l}\text { Affiliation: } \\
{ }^{1} \text { Department of Philosophy, } \\
\text { Practical and Systematic } \\
\text { Theology, University of South } \\
\text { Africa, South Africa }\end{array}$} \\
\hline \multicolumn{2}{|c|}{$\begin{array}{l}\text { Note: } \\
\text { This article is published in the } \\
\text { section Practical Theology } \\
\text { of the Society for Practical } \\
\text { Theology in South Africa. }\end{array}$} \\
\hline \multicolumn{2}{|c|}{$\begin{array}{l}\text { Correspondence to: } \\
\text { Marilyn Naidoo }\end{array}$} \\
\hline \multicolumn{2}{|c|}{$\begin{array}{l}\text { Email: } \\
\text { naidom2@unisa.ac.za }\end{array}$} \\
\hline \multicolumn{2}{|c|}{$\begin{array}{l}\text { Postal address: } \\
\text { PO Box 392, Unisa, Pretoria } \\
\text { 0003, South Africa }\end{array}$} \\
\hline \multicolumn{2}{|c|}{$\begin{array}{l}\text { Dates: } \\
\text { Received: } 24 \text { Mar. } 2014 \\
\text { Accepted: } 06 \text { Nov. } 2014 \\
\text { Published: } 29 \text { May } 2015\end{array}$} \\
\hline \multicolumn{2}{|c|}{$\begin{array}{l}\text { How to cite this article: } \\
\text { Naidoo, M., 2015, } \\
\text { 'Transformative remedies } \\
\text { towards managing diversity } \\
\text { in South African theological } \\
\text { education', HTS Teologiese } \\
\text { Studies/Theological Studies } \\
71(2), \text { Art. \#2667, } 7 \text { pages. } \\
\text { http://dx.doi.org/10.4102/ } \\
\text { hts.v71i2.2667 }\end{array}$} \\
\hline \multicolumn{2}{|c|}{$\begin{array}{l}\text { Copyright: } \\
\text { (C) 2015. The Authors. } \\
\text { Licensee: AOSIS } \\
\text { OpenJournals. This wor } \\
\text { licensed under the Crea } \\
\text { Commons Attribution } \\
\text { License. }\end{array}$} \\
\hline \multicolumn{2}{|l|}{ Read online: } \\
\hline 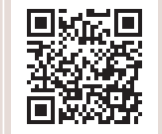 & $\begin{array}{l}\text { Scan this QR } \\
\text { code with your } \\
\text { smart phone or } \\
\text { mobile device } \\
\text { to read online. }\end{array}$ \\
\hline
\end{tabular}

South Africa is a complex society filled with diversity of many kinds. Because of the enormous and profound changes of the last 20 years of democracy, this can be perceived as a society in social identity crisis which is increasingly spilling over into many areas of life. Churches have also gone through a process of reformulating their identity and have restructured theological education for all its members resulting in growing multicultural student bodies. These new student constituencies reflect a wide spectrum of cultural backgrounds, personal histories and theological commitments, and represent diversity in race, ethnicity, culture, class, gender, age, language and sexual orientation. These issues of diversity are theologically complicated and contested as they are attached to religious dogma. Diversity exists as a threat and promise, problem and possibility. Using current conceptualisations of diversity in South African Higher Education this article will seek to understand the notion of diversity and difference and the possibility of developing transformative remedies within the theological education curriculum.

\section{Introduction}

South Africa is a complex society filled with diversity of many kinds. According to Booysen et al. (2007) 'research shows that the most salient social identity groups in South Africa are race, gender, ethnicity and language' (2007:1). In the new political era, many projects are targeting social upliftment and nation building to develop a 'normal' society, rich in diversity. According to Booysen et al. (2007):

$[O] \mathrm{n}$ the ground, however, South African society is a long way from reflecting this, as deep social divisions continue and the diversity of the population remains largely untapped as a resource - more often than not it is regarded as a source of difficulty. (p. 1)

Because of the enormous and profound changes of the last 20 years of democracy, this 'can be perceived as a society in social identity crisis' (Booysen et al. 2007:1) which is increasingly spilling over into many areas of life. Churches also have gone through a process of reformulating their identity and have restructured theological education for all its members resulting in growing multicultural student bodies (Dreyer 2012:505). These new student constituencies reflect a wide spectrum of cultural backgrounds, personal histories and theological commitments, and represent diversity in race, ethnicity, culture, class, gender, age, language and sexual orientation. These issues of diversity are theologically complicated and contested as they are attached to religious dogma. In dealing with 'otherness' educators cannot agree whether the goal is to 'understand' or to 'convert' or to bring them 'into the fold' or to explore the 'interconnectedness' (Foster 2002:21). For example, one of the most significant changes in theological education has been the increase in women students resulting in political leverage for feminist theological education that continues to challenge traditional practices in seminaries (Chopp 1995:iv).

In the context of the United States of America, theological institutions generally treat diversity as a matter of accommodation (Cascante 2010:32; Parades-Collins 2009). In some seminaries the institutional culture only saw the need to change some part of the life of the institution to accommodate new students or 'to include some content modules that reflect theological perspectives distinct from those of the dominant culture' (Aleshire 2009). According to RiebeEstrella (2009:20), the fundamental 'worldview of institutions and of pedagogy remains the same, whilst some accommodation is made for those who come from diverse cultures and ecclesial experiences'. This approach no longer seems viable, neither on institutional nor on theological grounds. This is seen in the Association of Theological Schools in the United States of America (body of about 250 accredited tertiary theological training institutions) with a growing number of international students, mostly from non-Western countries that emphasise that 'attention to diversity is not simply a matter of inviting participating, but a lens in the theological school's essential task of learning, teaching, research and formation' (Gilligan 2002:9). On the basis of 
the economics, seminaries cannot exist without recruiting students from other traditions. These students cannot be viewed as 'guests' but must be recognised as full participants in the life and ethos of the institution. In responding to changing student bodies, institutions are also called to respond to be transformed and need to reflect this diversity in its teaching staff as well.

Despite the efforts to increase diversity in theological education during the last three decades in the United States of America (Cascante 2010:21), some but not enough progress has been made. In general, 'the lenses of race, ethnicity, class, gender ... have been used as hermeneutical, pedagogical and critical perspectives on the production and function of knowledge in many disciplines' (Andraos 2012:4). According to Riebe-Estrella (2009:19), 'no new vision of theological education is being proposed in which differences are lifted and divisions are unmasked'. Rather, the institutional culture remains one of privilege for those in power as the dominant group and the central issues represented are those of the same dominant group, considered normative, whilst other issues are seen as of less value (Riebe-Estrella 2009:19).

In South Africa there is scarcity of literature on how diversity is managed in theological institutions. One wonders how theological institutions are dealing with diversity whilst forming students within its institutional culture, as this kind of socialisation is seen as most formative (Hindman 2002). It is important to raise this issue as in South Africa race still predominates with the continuing legacy of inequality and unjust power dynamics and hence suspicion abounds in trying to find constructive proposals to managing diversity.

Polarisation is evident in South African society; issues are dedicated by race as a key category (Steyn \& Conway 2010). In schools and universities, few people are talking about race issues, sometimes affirming that 'we don't have a problem here' (Smith, Stones, Peck \& Naidoo 2007). Carrim (2000) notes that:

[T]his culture of denial is related to at least three kinds of fear: (1) fear of losing privilege; (2) fear of continuing with the ways of the past; and (3) fear of civil strife. (p. 33)

Another author agrees with the reaction of racism by stating that:

[W]hatever the reasons, South African society's pre-occupation with not being pre-occupied with 'race' and racism provides an initial impetus for continued critical research, theorizing and study into these phenomena. (Stevens 2003:192)

Soudien (2010:352) also came close to argue that 'race' represents the generative mechanism through which other forms of difference are constituted, reconstituted, reinforced or gain expression. He states that racism is often intertwined with other forms of discrimination - based on social class, gender, ethnicity, religion, language, sexual orientation, and xenophobia - and uses these to justify and reproduce itself
(Soudien 2010:358). Indeed, we live in a deeply racialised society more than ever before, to quote Allan Boesak (2011) 'we are not a post-apartheid society, but a post-racial society'.

Religious organisations act as a go-between the private and public spheres and as such religious institutions can intervene to 'draw people out of their private, racially segregated lives, into a social space where human interactions are more intimate than the public arena' (Christerson, Edwards \& Emerson 2005:16). These types of racially mixed relationships can serve as a model or authentic type of social cohesion that is much needed in the broader South African society. However, the reality in far too many cases is that 'churches, the presumed agents of reconciliation are at best impotent and at worst accomplices in strife' (Volf 1996:36). Here one may question, for example, how the church in South Africa is dealing with racism, what kind of Christians such a church will form, and how are future ministers being prepared to deal with these issues of diversity. In addition, according to West (1994:20) there has been little understanding of the 'structural character' of diversity located in schools, churches or families. According to Cross et al. (1999:5) diversity is most prevalent in organisations that 'have strong institutional leadership and commitment at the management level'.

Using current conceptualisations of diversity in South African Higher Education this article will seek to understand this notion of diversity and the possibility of developing transformative remedies within the theological education curriculum. This analysis relies on the liberationist or emancipatory concept of praxis which can interrogate different kinds of injustice in the theological education environment.

\section{Diversity in South African Higher Education}

Generally 'diversity' remains an elusive and ambiguous concept not devoid of paradox. Diversity represents a mix of characteristics that makes each person or group unique. Goduka (1996:68) refers to diversity as the state of being diverse or different and may be based on ethnicity, race, class, gender, sexual orientation, ethnicity, religion or any point of difference. It must be emphasised that social markers of difference and privilege are neither innate nor innocent but the result of socially structured boundaries between individuals or social groups (Cross \& Naidoo 2012). The boundaries between different categories of social groups and knowledge are a function of power relations as 'power relations create boundaries, legitimize boundaries, reproduce boundaries between different categories of groups, gender, class, race, different categories of discourse, different categories of agents' (Bernstein 2000:5).

In South Africa conceptualisations of diversity underpinning diversity programmes, scholarship and curriculum practices and the 'different ways in which institutions have reworked, redefined and reinvented 
diversity is against the background of the apartheid legacy' (Cross et al. 1999:5). These range 'from "affirmation" or "celebration" of diversity, to diversity as a "strategy for embracing, or accommodating or engaging differences"' (Cross et al. 1999:5). In spite of their different or even conflicting assumptions, generally these conceptualisations converge on or point to the need for integrating the 'politics of cultural and identity recognition with the politics of social justice and equity' (Cross et al. 1999:5), which represent a key strength in South African diversity discourse.

Higher education institutions play an important role as sites where issues of tolerance, inclusion, access and structural inequities can be addressed effectively. Racial, cultural, social and linguistic diversity is being represented in South African institutions of higher education. Hence 'diversity', 'diversity issues' and 'diversification' have become part of the education debate and policy, and pose new challenges to South African tertiary institutions (Cross et al. 1999:7). Diversity as a civic value, involves new social competences and practices, and as Schneider (1997:128) suggests, developing capacities for 'engaging difference' is essential to the success of a diverse democracy. A commitment to diversity is manifested in the Constitution with the broad aim to create and nurture a non-racial, non-sexist, non-discriminatory society where all people can recognise each other's differences, whilst at the same time live in peace and harmony. As Smith and Schonfeld (2000:18) state 'issues of diversity, social justice and higher education are profoundly linked to the survival and well-being of democracy'.

Most universities, even academic departments of theology, as seen in the example of the University of the Orange Free State (Strydom \& Holtzhausen 2001), are attempting to respond to these challenges within the context of a transformation process which impacts on every aspect of academic life from student access and support, outreach programmes, staff recruitment and retention, to academic programme development, research, scholarship and the social and learning environment on campus. Cross (2004:401) states that institutions accused as having Eurocentric tendencies were challenged 'to Africanise their curricula and brought [sic] in some African Studies'. However, this has increased pressures to respond in an action-oriented mode resulting in pragmatic instrumentalism which has dominated 'intellectual formations' in the approaches to diversity knowledge (Cross 2004:389). Cross (2004:404) claims that an important dimension overlooked in diversity scholarship is a 'critical theory of recognition that supports only those forms of identity politics that can be coherently combined with a politics of social equity.'

According to Smith and Schonfeld (2000), growing evidence supports the notion that:

[F]aculty diversity (especially in race and gender) is linked to curricular change; the inclusion of issues of race, class, gender and sexual orientation in the educational process, diversification of scholarship and pedagogical perspectives; and support for diverse students. The presence of diversity in the student body ensures opportunity for intergroup interactions among all students and supportive subgroups of students. The visible presence of diversity in leadership at all levels contributes to positive perceptions about institutional commitment and climate. (p. 17)

In spite of this Cross et al. (1999) state that social integration programmes at South African institutions are not a priority because of the idea that they could symbolise a type of undesirable 'social engineering' instead of change forming organically. This speaks to the value of 'evolutionary' versus 'managed' change in higher education (Cross et al. 1999:7).

\section{Managing diversity in theological education}

Theological institutions educate students for service in a democratic and pluralistic society and need to confront the issues of society through engagement, research and service. From this perspective the very survival of institutions is contingent upon adaptation to the current culture. According to McMinn (1998:24) societal pressure is not the only source of 'push' - there are also forces within the institution that push toward this adaptation. Biblical teachings encourage Christians toward a religious praxis that is welcoming of different peoples as equal partners in faith. Theological education at the same time is focused at interrogating social inequalities as theology deals with basic beliefs and attitudes about the self, God community and society. According to Fubara et al. (2011):

$[T]$ hese internal and external forces push theological training institutions and seminaries toward greater pluralism, the institutions are also pulled toward greater homogeneity. Thus the need to preserve the institution's core values and beliefs makes it difficult for it to fully embrace those who do not look or sound like the majority of its constituents. (p. 115)

One of the reasons for example, Christian institutions in the United States of America struggle with diversity, even though all higher education sites must embrace pluralism and diversity, as they fear that embracing diversity will ultimately result 'in the college's atmosphere becoming contrary to the faith' (Abadeer 2009:189). Many seminaries fear that an unintentional by-product of incorporating diversity is that their campus will become politicised. In the United States of America, McMinn (1998:24) presents an enclave adaptation theory to explain why evangelical Christian institutions lag behind their secular counterparts in developing diverse student populations and a corresponding commitment to diversity.

Once theological institutions face the full magnitude of diversity there is a temptation to adopt a 'colour-blind' position that shields them from differences, rather than help the seminary community appreciate and learn from their experience (Aleshire 2009). This attempt to defuse cultural differences in an educational environment maintains the status quo, creating an ethos that favours the dominant group as the norm rather than the dynamism of 
unity within diversity (Hurtado 2005:600). Educators who apply this colour-blind approach often try to suppress and gloss over their prejudice by professing not to see colour. In addition, this could suggest that newcomers to the institution come from educationally and culturally inferior backgrounds and that adjusting the curriculum to meet these students' needs amounts to lowering the otherwise high standards (Meier \& Hartell 2009:180). Mafumo (2010) argues that assimilation produces a monocultural policy and leaves the dominant relationships, culture and ethos of the institution unchallenged. It is important to note that a lack of consciousness of the way in which institutions are organised and teach holds direct consequences for students' identity and transformation.

The aim of exploring diversity is to look at the ways in which difference is constructed, how its significance shifts, how it is operationalised in institutions and most critically why difference continues to matter. Critical diversity theory entails a fundamental look at the constructs of difference which underpin the culture of the institution and interpersonal interactions, and moves beyond merely tolerating or assimilating difference into dominant practices (Booysen et al. 2007:7). The eight analytical criteria listed below are used to evaluate the presence of diversity literacy:

1. A recognition of the symbolic and material, such as whiteness, heterosexuality, masculinity, able-bodiedness, etc.

2. Analytic skill at unpacking how these systems of oppression, intersect, interlock, co-construct and constitute each other.

3. The definition of racism as current social problems rather than a historical legacy.

4. An understanding that social identities are learned and an outcome of social practices.

5. The possession of diversity grammar and a vocabulary that facilitates a discussion of race, racism and antiracism, and the parallel concepts employed in the analysis of other forms of oppression.

6. An ability to translate (interpret) coded hegemonic practices.

7. An analysis of the ways that diversity hierarchies and institutional oppressions are mediated by class inequality.

8. An engagement with issues of transformation of these oppressive systems towards deepening democracy in all levels of social organization (Booysen et al. 2007:7).

These critical diversity interventions prepare the ground for transformation processors to be activated towards more fair approaches within organisations (Booysen et al. 2007:7). The definition above provides a distinction between difference management which encourages window dressing, and that which aims at profound transformation. Cross (2004:402) draws on Fraser's (1997) distinction between affirmative remedies and transformative remedies. For Fraser, affirmative remedies are aimed at correcting inequitable outcomes of social arrangements without disturbing the underlying framework that generates them (Fraser 1997:23). Affirmative remedies are currently associated with most programmes on multicultural education introduced in some institutions to redress disrespect by re-valuing unjustly devalued group identities and the group differentiations that underlie them. This is an add-on approach accomplished through quick fix remedies by inserting a multicultural course into an otherwise unreconstructed curriculum (e.g. adding a gender studies module to a curriculum that remains intact). Diversity issues are not tackled 'head-on', for example random programmes are organised or passing experts give talks. It does not involve a restructuring and a challenge to the canon of the curriculum. The main failure of affirmative remedies is their inability to promote equity and social justice effectively (Cross 2004:402). Affirmative remedies have the ability to shame the disadvantaged, adding the insult of misrecognition to the injury of deprivation. In contrast, transformative remedies (Fraser 1997:27) seek to put right inequitable outcomes precisely by 'restructuring the underlying generative framework', that is, the processes that produce them. They are associated with deconstruction, which means dismantling and deconstructing the legacy of the norm of old practices in order to reconstruct and transform the Eurocentric and racist curriculum to reflect the experiences, voices, struggles, victories, and defeats of all racial, ethnic, cultural, religious, and other social groups (Fraser 1997:27).

Developing transformative remedies within theological education would involve a curriculum which goes beyond subject content to access the underlying principles that give structure to the subject, a curriculum that includes " higher order knowledge" about how subject disciplines organise knowledge, and people's knowledge of how they think and learn' (Starfield 1996:160). Within the South African context, this approach will certainly require taking seriously the question of equity and social justice.

\section{Transformative remedies in the theological curriculum}

Diversity, according to Gilligan (2002:9), means 'resisting the homogenizing of racial, ethnic, cultural and class differences into uniformity'. Moreover, she views diversity as 'learning how diverse constituencies use power to control and shape the agenda of theological education and its mission, is critical' (Gilligan 2002:9). Power relations within social structures of race, class, gender or sexual orientations are examined by many scholarly disciplines like critical pedagogy, feminist pedagogy, anti-racist education and critical multicultural scholarship (Brookfields 1995:10). These theories focus on the analysis of power relationships between dominant and oppressed groups and make the assumption that structural social change will come about when power relations are challenged (Tisdell \& Tolliver 2003:370). The purpose of initiatives related to diversity is not to ferret out racists, but to examine the unrecognised ways in which power assumptions embedded in institutional culture might disenfranchise certain groups of students (Riebe-Estrella 2009:19), whether knowingly or unknowingly and undermine the educational mission of empowering students for work. 
In the classroom, the lens of colonial difference begs the question of the 'power of Eurocentric educational approaches that highly emphasize reason and individualism' (Andraos 2012:6). Eurocentrism and overwhelming economic power remain the pillars of whiteness and are its trump cards as it plays for power in the new dispensation (Steyn 2001). Eurocentric approaches are dominant in the field of theology influencing both the content and the way knowledge is communicated. As Aleshire (2009:15) from the Association of Theological Schools suggests, 'whether the theology taught in institutions is dogmatics or constructive theologies, it invariably focuses on Euro-westerner formulations of faith and philosophical thought.' As Beaudoin and Turpin (2014:254) suggest the very language of discourse that has developed is inherently racialised as white and normative. Andraos (2012) asks the question:

$[H]$ ow do we transcend the Eurocentrism of theological education in order to explore the epistemic potential of truly inter-cultural learning? How do we develop teaching methods that are respectful of and engage students from different racial and cultural backgrounds? How do we include voices and sources from other cultural perspectives in our reading? (p. 7)

According to Andraos (2012:7) it begins by 'acknowledging that the cultural, religious and theological knowledge represented in the classroom are not equally valued'. Using Mignolo's (2007:490-492) terms, persons who come from different places and think from different locations, that is from different world views, do not work together on equal footing. What is evident is a pecking order of systems and sources of knowledge, with the Western perspective at the top of the pyramid that is consistently supported in understated ways as universal. To challenge this world view will not only bring about a revolution but could threaten the core stability of the educational enterprise (Gilligan 2002). But there should be a discussion about maintaining the current theological 'canon' and about including 'other' voices in the conversation. This crucial issue is much deeper than simply adding black scholars to the syllabi. It has significant inference for the nature of theological discourse (Gilligan 2002); the redefining of who should be the 'gatekeeper' and who should be involved in the 'decolonisation' of the curriculum.

The colonisation process has brought about 'colonized minds and education systems' (Andraos 2012:6) which is a very involved form of power, more difficult to identify, resist and transform. The work of uncovering dominant Western paradigms of knowledge is not new. However, as Andraos (2012 quoting Mignolo) states not enough attention is given to epistemic decolonisation which attempts to unveil the:

[G]eo-political location of theology, secular philosophy and scientific reason and simultaneously affirming the modes and principles of knowledge that have been denied the rhetoric of civilization, progress, development and market democracy. (p. 7)

Andraos uses Mignolo's approach for decolonising knowledge, described as 'delinking', understood as a 'de-colonial epistemic shift leading to other-universality, and brings to the foreground other epistemologies, other principles of knowledge and understanding and consequently, other politics, other ethic' (Andraos 2012:7).

Androas (2012:10) suggests that through inter-cultural learning students can bring different knowledge from their respective traditions. In this way local knowledge and wisdom is valued with multiple theoretical frameworks instead of classical theoretical texts which can pressure students to use Western ideas to interpret their own experience and cultural contexts. This learning creates opportunities for de-linking (Androas 2012:10) from dominant ways of thinking, however it must not be limited to one course but must become mainstreamed within theological curricula and the learning environment. In this way the supremacy of the Eurocentric universality claim can be taken down so as to make space for other theological traditions to become genuinely included as equal partners in joint dialogue.

In Fighting the elephant in the room: Ethical reflections on white privilege and other systems of advantage in the teaching of religion, Hill, Harris and Martinez-Vazquez (2009:4) offer insightful pedagogical analysis and strategy for nurturing a liberating education that take the issues of social justice seriously. Their insightful pedagogical model involves:

1. engaging students where they are

2. helping them identify their identities and social locations

3. helping them acknowledge the reality of injustice and oppression, understood as sanctioning and nurturing of systems of inequality that are woven throughout social institutions and embedded within individual consciousness. (Hill et al. 2009:8)

Pedagogical strategies rooted in the anti-racist discourses place emphasis on critical thinking as the foundation for new meaning construction, self-discovery, and self-creation against the legacies of prejudice and alienation. Through exploration and reflection, students are challenged to question the taken-for-granted notion of their rootedness in a culture or a nation. To do this, students need to find a balance between involvement in and distance from the discourses surrounding them. They need to be involved so that they can influence the discourse, yet remain distanced enough to reflect. These reflections are undertaken within a multidisciplinary framework, similar to the forms of analysis advocated by womanist theologians in that issues of gender, class, sexuality and disability (how many used the terms 'male' or 'heterosexual' or 'able-bodied') are also discussed and reflected upon.

Hill et al. (2009:4) write of the elephant in the room as 'the complex nexus of systems of advantage, with a special focus on white privilege' invisible to most white people. In developing models of anti-racist and anti-oppressive practices for Christian ministry Reddie (2010) speaks of challenging unaware white students to reflect on what privileges and opportunities are accrued by the simple fact that they are white. It begins with an acknowledgement of the unearned privileges that whiteness confers. Whiteness 
studies is an emergent field that examines 'white inflections in which whiteness as a form of power is defined, deployed, performed, policed and reinvented' (Steyn \& Conway 2010:284). This work often takes a postcolonial perspective as there is a relationship between uncovering whiteness and decolonising the mind of both the oppressed and oppressors (Steyn 2001). The point of these practices is to conscientise students to the dynamics of difference to challenge assumptions so that difference is not seen negatively as a threat.

Anti-racist pedagogies can also be split into two camps: a strong anti-racist pedagogy and a weaker version of it (Cross \& Naidoo 2012). The strong version advocates direct interrogation of the racist discourse thus embracing the psycho-social violence embedded in this discourse and interrogating it as a legitimate pedagogical strategy (e.g. pedagogy of fear). In this perspective, discursive violence is assumed as having a humanising effect on the subjects. A weaker version advocates selective engagement with racist discourses, that is, in so far as classrooms are retained as 'safe spaces' that can only absorb benign forms of racist discourse and its sensitivities. The weak version has been referred to as the pedagogy of compassion or reconciliation. Jansen (2008) develops this latter version and takes a more daring approach on how to mediate anti-racism between the 'perpetrators' (white people) and the 'victims' (black people) of racism. He takes the notion further and proposes a postconflict pedagogy. Whereas anti-racist pedagogy and critical race theory demand white people to make the move towards black people; a post-conflict pedagogy requires both to engage in this relationship. Dealing with such a complexity, where the perpetrators and the victims share the experience of pain and suffer from different kinds of trauma that require healing - this points to a pedagogical strategy of compassion or reconciliation. Learning to see the humanity of the other and the religious dignity is a first step toward dialogue. This post-conflict pedagogy focused on diversity fits the Christian ideal as an opportunity for empowerment, healing of memories and reimagining racial, cultural and religious reconciliation.

Handling diversity is a complex task and educators need to recognise the validity of differences which will require an appraisal of the educator's own personal positioning and of the institution's ideologies, and a candid commitment to facilitate and manage student diversity (Meier \& Hartell 2009:180):

\begin{abstract}
At a very deep level, people working with diversity issues are involved in changing people's social identities. It is not sufficient to merely train people to understand people's cultural differences at a superficial level. More profoundly, teachers and students need to have a deep grasp of their own social and personal contradiction. (Grant 2007:94)
\end{abstract}

That requires soul-searching and self-reflexivity. Equally important to recognise is that the act of speaking in unchanged spaces is not always easy, and is itself influenced by the problems related to how one is perceived in racialised ways in these spaces (Meier \& Hartell 2009). And often it is in the silences, the unspoken, that the effects of racism may be understood. Fear, indifference and selective noninvolvement can present itself, frustrating attempts at diversity.

When institutions 'do not employ initiatives for diversity or engage in a passive role as it relates to race relations on campus, negative reactions and misunderstandings amongst students will occur' (Allen 2006:203). Steele (1995) reminds us that:

$[O] n$ our campuses, such micro-societies, all that remain unresolved between blacks and white, all the old wounds and shames that have never have been addressed, present themselves for attention - and present our youth with pressures they cannot always handle. (p. 177)

Here one might ask why South Africa needs to find a 'business case' for diversity when the moral one is so clearly evident (Booysen et al. 2007:10). However, the moral case is not clearly evident, 'as cultures of whiteness and power discourses of resistance actively continue to obscure enduring social and economic inequality and legacies of apartheid' (Steyn \& Conway 2010:283).

\section{Conclusion}

This article has shown that diversity indeed exists as a threat and a promise, a problem and a possibility. As Speller and Seymour (2002) state so clearly:

[T] he problem diversity poses is to locate a common intersection, among and between the ideas, myths and dreams undergirding the various types of difference and then to create an educational and conversational space sturdy enough to allow the restructuring of 'what counts' as theological education. (p. 60)

Within theological institutions, once the institutional culture begins to see its own situatedness, it can begin to shed its parochial and paternalistic tendencies (Foster 2002:16). This is only possible when 'whiteness' or 'blackness' or heterosexuality or being male is no longer conceived as the norm and is seen as one contextual position amongst many, albeit often carrying with it particular privileges and considerable power. In developing these transformative remedies for theological education, this becomes an opportunity to 'live out the Gospel, institutionally' (Speller \& Seymour 2002:61) with a vision of inclusion. It is a chance to create an enhanced educational environment that can be a 'space for debate and learning as well as dissonance and reconciliation' (Speller \& Seymour 2002:61) whilst developing religious leaders that will play an effective part in South African society.

\section{Acknowledgements}

This research was supported by grants from the National Research Foundation and is gratefully acknowledged. 


\section{Competing interests}

The author declares that she has no financial or personal relationship(s) that may have inappropriately influenced her in writing this article.

\section{References}

Abadeer, A., 2009, 'Seeking redemptive diversity in Christian institutions of higher education: Challenges and hopes from within', Christian Higher Education 8(3), 187-202. http://dx.doi.org/10.1080/15363750902782373

Aleshire, D.O., 2009, 'Gifts Differing: The educational value of race and ethnicity', Theological Education 45(1), 1-18.

Allen, W.R., 2006, 'Sticks, stones, and broken bones: Rhetoric and reality in the University of Michigan affirmative action cases', in W. Allen, M. BonousHammarth \& R. Teranishi (eds.), Higher education in a global society: Achieving diversity, equity, and excellence, pp. 203-226, Elsevier, San Diego. http://dx.doi. diversity, equity, and excellence, pp. 203-
$\mathrm{org} / 10.1016 / \mathrm{S} 1479-358 \times(05) 05010-2$

Andraos, M.E., 2012, 'Engaging diversity in teaching religion and theology: An intercultural, de-colonial epistemic perspective', Teaching Theology and Religion 15(1), 3-15. http://dx.doi.org/10.1111/j.1467-9647.2011.00755.x

Beaudoin, T. \& Turpin, K., 2014, 'White practical theology', in K. Cahalan \& G.S. Mikosk (eds.), Opening the field of practical theology: An introduction, pp. 250-269, Rowman \& Littlefield, Plymouth.

Bernstein, B.B., 2000, Pedagogy, symbolic control, and identity: Theory, research, critique, Rowman \& Littlefield, London.

Boesak, A., 2011, 'Church activism and the non-racial ideal', Paper presented at University of South Africa, public lecture, 01 July, 2011.

Booysen, L., Kelly C., Nkomo M.S. \& Steyn, M., 2007, 'Rethinking the diversity paradigm: South Africa practices', International Journal of Diversity in Organizations, Communities and Nations 7(4), 1-10.

Brookfields, S., 1995, Becoming a critically reflective teacher, Jossey-Bass, San Francisco.

Carrim, N., 2000, 'Critical anti-racism and problems in self-articulation forms of identities', Race Ethnicity and Education 3, 26-44. http://dx.doi.org/10.1080/ 713693013

Cascante, F.A., 2010, 'A decade of racial/ethnic diversity in theological education: The continuous challenge of inclusion with justice', Journal of Race, Ethnicity and Religion 1(3), 1-32.

Chopp, R.S., 1995, Saving Work: Feminist Practices of Theological Education, Westminister John Knox, Louisville.

Christerson, B., Edwards, K.L. \& Emerson, M.O., 2005, Against all odds: The struggle for racial integration in religious organizations, New York University Press, New York.

Cross, M., 2004, 'Institutionalising campus diversity in South Africa higher education: Review of diversity scholarship and diversity education', Higher Education 47, 387-410. http://dx.doi.org/10.1023/B:HIGH.0000020854.04852.80

Cross, M., Cloete, N., Beckham, E.F., Harper, A., Indresan, J. \& Musil, C. (eds.), 1999, Diversity and unity: The role of Higher Education in building democracy, Maskew Miller Longman, Cape Town.

Cross, M. \& Naidoo, D., 2012, 'Race, diversity pedagogy: Mediated learning experience for transforming racist habitus and predispositions', Review of Education, Pedagogy, and Cultural Studies 34(5), 227-244. http://dx.doi.org/10.1080/1071 4413.2012.735558

Dreyer, J.S., 2012, 'Practical theology in South Africa', in B.J. Miller-McLemore (ed.), The Wiley-Blackwell Companion to Practical Theology, pp. 505-514, WileyBlackwell, Oxford.

Foster, C.R., 2002, 'Diversity in theological education', Theological Education 38(2), 15-37.

Fraser, F., 1997, Justice interruptus - critical reflections on the 'postsocialist' condition, Routledge, New York.

Fubara, E.I., Gardner, M.T. \& Wolff, J.S., 2011, 'Applying diversity management principles to institutions of Christian Higher Education', Christian Higher Education 10(2), 112-131. http://dx.doi.org/10.1080/15363751003715767

Gilligan, M., 2002, 'Diversity and accreditation: A measure of quality', Theological Education 38(2), 1-13.

Goduka, I.N., 1996, 'Reconstructing education to affirm unity and diversity', South Africa Journal of Higher Education 10(2), 67-74.
Grant, T., 2007, 'Transformation challenges in the South African workplace: A conversation with Melissa Steyn of iNCUDISA', Business Communication Quarterly 70, 93-98. http://dx.doi.org/10.1177/108056990707000117

Hill, J.A., Harris, M.L. \& Martinez-Vazquez, H.A., 2009, 'Fighting the elephant in the room: Ethical reflections on white privilege and other systems of advantage in the teaching of religion', Teaching Theology \& Religion 12(1), 3-23. http://dx.doi. org/10.1111/j.1467-9647.2008.00471.x

Hindman, D.M., 2002, 'Form splintered lives to whole persons: Facilitating spiritual development in college students', Religious Education 97 (2), 165-182. http://dx.doi. org/10.1080/00344080290060923

Hurtado, S., 2005, 'The next generation of diversity and intergroup relations search', Journal of Social Issues 61(3), 595-610. http://dx.doi.org/10.1111/j.15404560.2005.00422.x

Jansen, J.D., 2008, 'Bearing Whiteness: A Pedagogy of compassion in a time of trouble', The Fifth Annual Hans Brenninkmeijer Memorial Lecture, Catholic Institute of Education, Johannesburg, 17th July, 2008

Mafumo, N., 2010, 'Managing Racial Integration in South African public Schools: In defence of democratic action', PhD thesis, Dept. of Education Policy Studies, Stellenbosch University.

McMinn, L.G., 1998, 'Enclave adaptation, multiculturalism and evangelical Christian colleges', Research on Christian Higher Education 5, 23-52.

Meier, C. \& Hartell, C., 2009, 'Handling cultural diversity in education in South Africa', SA-eDUC Journal 6(2), 180-192.

Mignolo, W.D., 2007, 'Delinking: the rhetoric of modernity, the logic of coloniality and the grammar of de-coloniality', Cultural Studies 21(2/3), 449-513. http://dx.doi. org/10.1080/09502380601162647

Parades-Collins, K., 2009, 'Institutional priority for diversity at Christian institutions', Christian Higher Education 8, 280-303. http://dx.doi.org/10.1080/ 15363750902821197

Reddie, A.G., 2010, 'Teaching for racial justice: A participative approach', Teaching Theology and Religion 13(2), 95-109.

Riebe-Estrella, G., 2009, 'Engaging borders: Lifting up difference and unmasking division', Theological Education 45(1), 19-26.

Schneider, C.G., 1997, 'From diversity to engaging difference: A framework for higher education curriculum,' in N. Cloete, J. Muller, M.W. Makgoba \& D. Ekong (eds.) Knowledge, identity and curriculum transformation in Africa, pp. 101-132, Knowledge, identity
Longman, Cape Town.

Smith, D.G. \& Schonfeld, N.B., 2000, 'The benefits of diversity: What the research tells us', About Campus, November - December, 16-23.

Smith, T.B., Stones, C.R., Peck, C.E. \& Naidoo, A.V., 2007, 'The association of racial attitudes and spiritual beliefs in post-apartheid South Africa', Mental Health, Religion and Culture 10(3), 263-274.

Soudien, C., 2010, 'The reconstitution of privilege: Integration in former white schools in SA', Journal of Social Issues 66(2), 352-366. http://dx.doi.org/10.1111/j.15404560.2010.01649.x

Speller, J.M. \& Seymour, J.L., 2002, 'Reflections on institutional issues relate to race and ethnicity in ATS Schools', Theological Education 38(2), 55-70.

Starfield, S., 1996, 'The challenge of diversity: Staff, students and curriculum development', South African Journal of Higher Education 10(1), 155-163.

Steele, S., 1995, 'The recoloring of campus life: Student racism, academic pluralism and the end of the dream', in J. Arthur \& A. Shapiro (eds.), Campus wars: Multiculturalism and the politics of difference, pp. 176-187, Westview Press, Boulder.

Stevens, G., 2003, 'Academic representations of 'race' and racism in psychology: Knowledge, production, historical context and dialectics in transitional South Africa', International Journal of Intercultural Relations 27, 189-207. http://dx.doi. Africa', International Journal of Intercu
org/10.1016/S0147-1767(02)00092-5

Steyn, M., 2001, Whiteness just isn't what it used to be: White identity in a changing South Africa, State University of New York Press, Albany.

Steyn, M. \& Conway, D., 2010, Introduction; Intersecting whiteness, interdisciplinary debates',Ethnicities 10(3),283-291.http://dx.doi.org/10.1177/1468796810372309

Strydom, A.H. \& Holtzhausen, S., 2001, 'Transformation and institutional quality management within a South African university: A case study of the University of the Orange Free State', Paris: UNESCO, Paris, viewed 15 October 2014, from http://unesdoc.unesco.org/images/0012/001248/124832e.pdf

Tisdell, E.J. \& Tolliver, D.E., 2003, 'Claiming a sacred face: The role of spirituality and cultural identity in transformative adult higher education', Journal of Transformative Education 1(4), 368-392. http://dx.doi.org/10.1177/1541344603257678

Volf, M., 1996, Exclusion and embrace: A theological exploration in learning and teaching, Oxford, New York.

West, C., 1994, Race matters, Vintage Books, New York. 